\title{
A Novice Bilingual Teacher's Journey: Teacher's Noticing as a Pathway to Negotiate Contradictory Teaching Discourses
}

\author{
Sandra I. Musanti \\ University of Texas Rio Grande Valley
}

U. S. A.

ABSTRACT: This qualitative case study investigates a fourth grade novice bilingual teacher's repertoire of practice during her first year of teaching. Drawing on recent work on teacher noticing, the study explores how the teacher negotiates prevailing bilingual education discourses. Two themes are discussed: how this novice teacher embraced bilingual teaching while questioning practices and policies and how she negotiated contradictions through multiple attempts to redefine her teaching practices. Findings show how the teacher's ability to notice framed her possibility to bridge her understandings about teaching, her critical pedagogical discourse, and the contextual contradictory discourses predominant in her school about bilingual education.

KEYWORDS: bilingual education, novice teacher, teacher noticing, repertoire of practice, teacher development

\author{
Theoretical Framework \\ Methods \\ Findings \\ Discussion and Implications \\ Note \\ References \\ Acknowledgements \\ Author Contact
}

The growing number of bilingual Latino students in the United States is well documented (García \& Jensen, 2010). The need for quality teachers is more acute for disadvantaged students (Isenberg et al., 2013) and bilingual learners (FrancoFuenmayor, Padrón, \& Waxman, 2015; Téllez \& Varghese, 2013). Moreover, research asserts that teachers are the most critical factor in students' achievement (Stronge, Ward, \& Grant, 2011). Therefore, it is important that teachers who enter the profession are prepared and receive support to address the learning and linguistic needs of Latino bilingual students. Demographics from the South Texas border reveal an even greater need to address these concerns, given that the majority of the student population there is classified as Hispanic and English language learners (ELLs). In addition, the areas of highest need for certified 
teachers in the region are in bilingual and English as a Second Language elementary education and for early childhood teachers (Uro \& Barrio, 2013).

Studies on early career teachers' voices and experiences can contribute to understanding novice teachers' needs in terms of support systems and teacher preparation, which might ultimately benefit students' outcomes (Anderson \& Olsen, 2006; Snyder, 2012). Listening to the voices of Latina teachers is particularly relevant in the field of bilingual education (Ochoa, 2007). There is a need for research that expands our understanding of how bilingual novice teachers grapple with the challenges of becoming a teacher in the current education climate in areas like Texas and in contexts, such as South Texas, where bilingual education is still contested (Hinton, 2014; Palmer, 2011).

The goal of this research was to gain a better understanding of a novice bilingual teacher's experiences and her evolving vision of what being a bilingual teacher in South Texas entails. Specifically, the study investigated a novice bilingual teacher's repertoires of practice during her first year of teaching, and how she engaged in negotiating prevailing and contested bilingual education discourses.

Two research questions guided this case study:

1. What do a novice bilingual teacher's repertoires of practice reveal about her understandings of students' needs and the instructional practices that better support learning?

2. How do her repertoires of practice reflect how she engages in negotiating prevailing and contested bilingual education discourses?

\section{Theoretical Framework}

This study is grounded in an understanding of teachers' development as a process of participation in sociocultural practices in interaction with others and the community (Rogoff, 2003; Rogoff, Baker-Sennett, Lacasa, \& Goldsmith, 1995). From this perspective, novice teachers and their changing repertoires of practices are mutually defined with those of the institutions they are part of and within dynamic cultural processes. Accordingly, teachers' trajectories can be understood in terms of transformation of their repertoires of practice more than the mere acquisition of new practices (Rogoff, 2003). Gutierrez and Rogoff (2003) defined teachers' linguistic and cultural repertoires of practice "in terms of their familiarity with engaging in particular practices on the basis of what is known about their own and their community's history" (p. 22). Moreover, when teachers enter the profession, their expectations, their understanding of the role of teaching, and their repertoires of practices are informed by the "cultural script" (Stigler \& Hiebert, 1999) of schooling, by their lifetime of experiences, and through the apprenticeship of observation and participation (Lortie, 1975).

Understanding novice teachers' repertoires of practice involves locating 
them in the constellation of institutional, social, cultural and linguistic discourses that they are part of instead of in isolation (Gee, 1990; Rogoff et al., 1995; Young, 2009). Novice teachers' repertoires of practice are evolving and situated in their trajectory from teacher preparation programs to public school classrooms. In this process, novice teachers actively engage in appropriating and enacting discursive practices (Young, 2009) that grant meaning to their beliefs about teaching and learning and legitimize their way of thinking and acting as teachers.

\section{Discourses on Practice and Teacher Noticing}

In the process of transitioning from teacher preparation to the school system, novice teachers encounter a range of discourses about teaching and learning that sometimes are contradictory or contested. For instance, the way bilingual education is defined by teacher preparation programs in higher education institutions might be at odds with how school districts provide bilingual services to English learners (Hinton, 2014; Palmer, 2011). Discursive practice involves "the construction and reflection of social realities through actions that invoke identity, ideology, belief, and power" (Young, 2009, p. 1). Thus, to define the type of discourses that underscore novice teachers' practices, this study draws on research that examines the impact of contextual discourses on teachers' critical pedagogical discourse (Thompson, Windschitl, \& Braaten, 2013), the role of language ideology in framing teacher's practice in bilingual programs (Palmer, 2011; Palmer \& Martínez, 2013; Stritikus \& Garcia, 2003), and recent work on the practice of teacher noticing in learning to teach (Barnhart \& van Es, 2015; Jacobs, Lamb, \& Philipp, 2010).

Thompson et al. (2013) examine how novice teachers "negotiate among different, often competing messages, norms, and practices in various learning-toteach settings (we refer to these as contextual discourses) and how they individually develop discourses (critical pedagogical discourses) that define and shape their emerging repertoires of practice" (p. 575). They postulate a theory of novice teacher practice that identifies critical pedagogical discourses and contextual discourses as a way to articulate teacher development within the institutional and community context in which it is situated. Critical pedagogical discourses are defined as the individual narratives and theories on what counts as good practice, learning, and knowing. Important to notice is that "critical pedagogical discourses are not necessarily consistent with teaching choices, but reflect what individuals believe should have been done even if they cannot or will not translate these discourses into action" (p. 579). In this study, critical pedagogical discourses are also connected to the idea of teacher ideology - the set of beliefs held as truth (Palmer, 2011) - that impacts how teachers approach instruction with linguistically and culturally diverse populations (Bartolomé \& Balderrama, 2001).

According to Thompson et al. (2013), contextual discourses are those theories about teaching and learnig that novice teachers are exposed to, which are 
communicated by other institutional actors (e.g., university courses, supervisors, school principal, professional development) through different types of social interactions. Contextual discourses involve different messages and ideas in relation to practice that might or might not "resonate with [teachers] developing theories of teaching and learning" and "may become internalized as critical pedagogical discourses and in turn influence pedagogical decisions" (p. 580).

An element not sufficiently addressed in the work of Thompson et al. (2013) is the role of shifting power relations as novice teachers engage in participating in different communities of practice (i.e., HEl or school districts) and as they encounter contradictory educational discourses. Considering the sociopolitical context of this study, these relations are particularly relevant given the predominance of policies and school practices that legitimize discourses of English-only education or reduced bilingual education to early exit or transitional programs whose main goal is to transition students as fast as possible from primary-language instruction to English-language instruction (Palmer, 2011). The dominating language ideology supports a subtractive approach to bilingual students' instruction: moving them as fast as possible to English-only instruction without native language support (Stritikus \& Garcia, 2003). In her study of teachers' language ideologies, Palmer (2011) explores the specific linguistic and cultural discursive practices that underscore this approach to bilingual education. This type of bilingual programs is rooted in a monolingual English ideology that defines bilingualism as a problem and bilingual programs as the strategy for English learners to overcome their language deficit (Hinton, 2014; Palmer, 2011; Palmer \& Martínez, 2013).

Even in the context of restrictive language policies, teachers position themselves and interact with the dominant contextual discourses (Stritikus \& Garcia, 2003). It is important that bilingual novice teachers develop a capacity to notice and move them to action in favor of students' language and learning needs. A growing body of research, especially in the field of mathematics teacher education, has identified teacher noticing as a core practice in learning to teach (Amador, 2014; Barnhart \& van Es, 2015; Gibson \& Ross, 2016; Jacobs et al., 2010). Teacher noticing is teachers' ability to observe students' work and interaction along with their capacity to reflect and analyze the meaning of the observations and then use that information to decide on a way to respond to student needs (Barnhart \& van Es, 2015). Jacobs et al. (2010) explain that teacher noticing involves three critical elements: (a) identifying noteworthy aspects of a classroom situation, (b) using knowledge about the context to reason about the classroom interactions, and (c) making connections between the specific classroom events and broader principles of teaching and learning (p. 171). The role of teacher noticing in the field of bilingual education as a component of a bilingual teacher's repertoire of practice remains unexplored. 


\section{Research on Novice Bilingual Teachers}

"Expanding what we know about Latina/o teachers is an important step in increasing the diversity of our teaching force, recognizing the contributions of Latina/o educators, and allowing others to learn from their approaches to schooling, students, learning, and education" (Ochoa, 2007, p. 8). However, research that documents novice Latina/o bilingual teacher experiences, pathways through practice, and struggles is scarce. Most of the available literature explores novice teachers' belief systems (Osterling \& Webb, 2009), their self-perception as language speakers (Thompson \& Fioramonte, 2012), Spanish language proficiency (Guerrero, 2003), and issues related to their cultural and professional identity (Galindo, 2007; Musanti, 2014; Prieto, 2013; Varghese, 2006). Osterling and Webb (2009) examined novice teachers' philosophy statements to identify how their beliefs, values, and views about teaching and learning changed as a result of their learning in a graduate education program. Other studies explored bilingual Latina teachers' cultural identities and how those identities are developed and enacted (Clark \& Flores, 2001; Clark, Jackson, \& Prieto, 2011; Musanti, 2014; Prieto, 2013; Varghese, 2006). For instance, Prieto (2013) explored two Latina bilingual education teachers' narratives to identify their beliefs, values, and approaches to teaching. The analysis illustrates how their development as bilingual teachers integrates a sense of self, family, and community. Studies have also addressed issues of academic Spanish language proficiency in terms of their implications for teaching, teacher identity, and bilingual education access and policy (Guerrero, 2003; Sutterby, Ayala, \& Murillo, 2005). Guerrero (2003) studied four US-born bilingual teachers and described their struggles as they engaged in learning and using academic Spanish as prospective and novice teachers. He argues that their struggle portrays institutional restrictions in terms of schooling experiences that granted access to academic Spanish. In addition, research investigates how teacher education programs and teachers' experiences contribute to shape bilingual novice teachers' learning trajectories. Arce (2004) studied how bilingual Latino educators who were prepared to teach underserved children embraced a critical pedagogy to develop identity and voice for both students and teachers. She concludes that "educators can find avenues to resist ideological and cultural hegemony" and that "bilingual teachers critically reflected on their situations as cultural and political workers" (p. 242).

\section{Methods}

The research described in this article is an exploratory qualitative case study of a novice bilingual teacher in South Texas. Yin (2003) defines a case study as empirical inquiry that produces an in-depth examination of a complex phenomenon "within its real life context" (p.13). This case study was an opportunity to learn from Ms. Perez's (a pseudonym) experiences as a novice teacher and 
ultimately to gain some insights on how we can support preservice teachers during their teacher preparation years. In preparation for the study, I discussed with Ms. Perez my vision for the study, the scope of my role, and the goals of the project (Dyson \& Genishi, 2005). I envisioned my role not just as an external observer but as an occasional observant companion during those first years of teaching. I was always an active listener, sometimes proposing, suggesting, and commenting on her ideas and practice. This approach defines my positionality as researcher and defines the study's potential bias as well as its strengths. After formally obtaining district permission, IRB approval, and Ms. Perez's consent to participating in the research, we agreed on the frequency of my visits and on what group of students and class period to observe.

\section{Context}

The case study took place in a small school district in South Texas, approximately 30 miles from the US-Mexico border. This school district is part of a region that has been described as one of the poorest areas in the United States with a per capita income less than half the national average (Lopez, 2006) and with $75.5 \%$ of the students classified as Economically Disadvantaged (District Data, $2015^{1}$ ).

Student population in this school district is mostly Latino (91\%); $8.75 \%$ of students are identified as English as Second Language (ESL) and $24.51 \%$ as bilingual learners whose first language is Spanish (District Data, 2015). ESL and bilingual students are entitled to receive support and instruction in their first language (Texas Education Agency, 2015). The district expects students to transition from the ESL/bilingual program to a "regular all-English program" when the students reach fluent level in English and meet state assessment criteria (Texas Education Agency, 2015).

\section{Participant}

Ms. Perez is a graduate from the Early Childhood-6 bilingual certification program at a regional university. She completed the state certification as a bilingual teacher. Ms. Perez grew up in Houston and moved to South Texas in $7^{\text {th }}$ grade. Her parents are Mexican immigrants. Even though her mother spoke Spanish to her, she grew up speaking English and received scarce support in Spanish during her elementary schooling experience. She perceived her Spanish proficiency as lacking, especially her writing skills. I first encountered Ms. Perez as a student teacher in one of my courses at the university.

Ms. Perez was one of two bilingual fourth grade teachers in the school. At the time of the study, she was teaching reading and language arts and science. The other bilingual teacher taught mathematics and social studies. They shared 
the same groups of students who rotated between classrooms depending on the schedule. In $4^{\text {th }}$ grade, instruction gravitates around the areas tested by the state (STAAR test): reading, writing, and mathematics. Ms. Perez's classroom included three different groups of fourth grade students classified by the district as bilingual students and placed in what the school identifies as a bilingual classroom. The groups were organized by level of language proficiency as determined by the school language proficiency assessment committee. She described the early morning groups as "high or high advanced" in English and instruction for those groups was exclusively in English. The third group included students who were classified as advanced or intermediate English speakers with a small group of five students classified at a beginning level. Based on the results of the language assessment test in place, this small group of students was identified to receive instruction in Spanish. These students also received ESL pull-out services.

\section{Data Collection}

Data were collected during the first year of Ms. Perez's teaching career and involved semistructured interviews, classroom observations, and unstructured debriefing conversations. In addition, I collected different artifacts such as pictures of classroom materials (e.g., anchor charts, word walls, worksheets) and lesson plans.

Semistructured interviews, conducted twice, included open-ended questions, lasted approximately 30 minutes, were audio-recorded, and later transcribed. The interviews were designed to explore the teacher's ideas about practice, and her rationale to develop and implement specific practices to support bilingual students. Questions also explored the practices she identified as more effective, her experience with planning and teaching, and her accomplishments and challenges.

Classroom observations, conducted nine times, occurred approximately every three weeks during the class period involving Spanish instruction to the small group of students. The observation focused on taking descriptive notes (Dyson \& Genishi, 2005) of teaching practices during different segments of instruction. I observed on different weekdays to collect data from a wider range of lessons and content. My fieldnotes followed the language of instruction: when the teacher was using English, I wrote in English; when the teacher was using Spanish, I wrote my notes in Spanish. The visits to Ms. Perez's classrooms were also documented through a researcher's log. The log and the fieldnotes also included reflective notes that documented the research trajectory, making sure critical moments would not go unnoticed (Dyson \& Genishi, 2005).

Unstructured debriefing conversations, conducted seven times, occurred after each observation and when the teacher schedule allowed it. Our conversations focused on how she was approaching the instruction of Spanishspeaking students, her struggles and concerns, and any other relevant topics (e.g., 
testing). These informal conversations proved to be a valuable source of information as they provided a vivid picture of what was occurring at the moment, what the teacher was thinking, and how she was dealing with different situations as they presented. The interviews and conversations were primarily in English but, as we were both bilingual, sometimes interaction naturally switched to Spanish.

\section{Data Analysis}

I used an inductive process of data analysis, initially focusing on sorting the data in terms of the content and later moving into identifying different types of practices and discourses across the data. Initially, I read throughout the fieldnotes and transcripts, making marginal notes. These notes identified different types of practices that addressed language and content needs of bilingual students and, specifically, her group of Spanish speakers (Dyson \& Genishi, 2005). Following the research questions, I refined the initial list of marginal notes into a more focused set of codes to apply across the data. Analyzing the trajectory of her repertoire of practices required a close look at how the practices evolved over time. Then, I created a matrix to display the data by codes, data source, and point in time of data collection. I coded transcribed data, looking for instances of teacher questioning, identifying, or describing practice; teacher noticing; teacher questioning or describing school practices or policies; and teacher negotiating contradictory discourses. Fieldnotes were coded with attention to identify types of practice (i.e., test strategy, vocabulary, revoicing, background knowledge, among others), use of language (Spanish or English), and teacher noticing (evidence of teacher identifying a need and acting on it). A third reading involved a longitudinal review of each set of data, identifying patterns and contradictions within and across categories (Yin, 2003). This analysis rendered themes that I reorganized and grouped based on my research questions and theoretical framework (Dyson \& Genishi, 2005).

\section{Findings}

It was October, Ms. Perez's third month in her first year of teaching in a fourth grade bilingual classroom in a small town close to the US-Mexico border. The day on which we met for the first time in her new classroom, she shared with me her inner feelings: "As this week kept going on, ... I felt [for] my Spanish kids, like this week I completely failed. I felt I lost them, I didn't think I did what I was supposed to be doing" (October, Interview). Ms. Perez's words reflect what seems to be a growing gap between the realities and demands that bilingual teachers confront, as they become part of the school system in South Texas, and what they learn in the bilingual teacher preparation programs.

By focusing the analysis on what this bilingual novice teacher noticed, two themes were identified to describe how this teacher's trajectory of practice evolved 
throughout the first year. The first theme explores how she understands students' needs and the instructional practices that could better support the learning process of the English learners receiving Spanish instruction in her class (research question 1). The second theme contributes to uncovering how this novice teacher engages in negotiating contextual discourses about bilingual education practices (research question 2)

\section{Defining What Bilingual Teachers Do: Noticing as Questioning Practices}

During the first part of the year, Ms. Perez repeatedly shared her efforts at trying to identify how to approach instruction in her classroom. "I am not doing what I am supposed to be doing," she mentions as she describes her struggle trying to figure out how to teach both in English and Spanish to one of her groups. During her first year, this novice teacher found herself trying to plan instruction to three different groups with different learning needs in terms of content and language development. She was the only bilingual teacher in her school teaching reading and writing to fourth graders. Even though the school district provided a fullydeveloped curriculum of what to teach on a weekly basis, she was expected to implement the same curriculum for a group of students in Spanish while simultaneously teaching the content in English to the rest of her students. That is, one of the three groups she taught included five students with a beginning level of English language proficiency who were supposed to receive Spanish instruction. Moreover, this group of students had to complete the State standardized test in Spanish and the rest of her class in English. Building on her critical pedagogical discourse (Thompson et al., 2013) about what it entails to teach in a bilingual classroom, she tried different teaching strategies, using either Spanish or English as the language of instruction, and analyzed the impact based on how she perceived her students were doing. For instance, initially she used to translate for her Spanish dominant students, even when she had learned in her teacher preparation program (TPP) that the strategy is not effective. Using the translation strategy afforded her the opportunity to notice its shortcomings. Later, she used an adaptation of the translation strategy, teaching side by side, that is, teaching the content in English and immediately after teaching it in Spanish. She also noticed the shortcomings of this strategy in terms of its doability (time consuming) and its effectiveness in promoting conceptual understanding. She implemented a third strategy separating "Spanish speaking students" from the rest of the group when delivering English instruction by assigning them a different task. The outcome was not what she expected. She noticed that the "Spanish group" of students was falling behind. Ms. Perez struggled, trying to find a different way to approach instruction using both languages while integrating all students.

During the second part of the year, Ms. Perez's noticing focused on using knowledge about the community and cultural context to reflect on classroom interactions (Jacobs et al., 2010). As a result, she seemed to achieve a more nuanced understanding of students' needs. She noticed individual needs as well 
as group needs, and she was able to address both in different ways. "I started to open my eyes to everything," (January, conversation) she explains after she noticed that one student was struggling and his grades had dropped significantly. She decided to approach the student who confided he missed his dad, a Mexican migrant worker. Now, her repertoire of practice allowed her to identify a range of needs and issues impacting students.

I started to see what affects them more often.... I guess I really didn't connect it when I was in the University, I would hear... all these are factors that affect kids when they're in school, but never knew first hand and now I see it. I see how everything affects their world and how they're thinking and how they're doing at work and school. (January, conversation).

This was an important realization to broaden her understanding of bilingual instruction as not only focused on the use of one or the other language but on integrating the sociocultural realities of her students.

Similarly, she was able to interrogate her own practice in a more nuanced way. She noticed that her approach to teaching "Spanish kids" was still lacking. "I guess one of the biggest reflections that I had and I know I should have focused a little bit more on, how can I put this, ... with my Spanish students" (May, interview). She explains how her emphasis and time dedication to teach reading and writing strategies to prepare students to pass the state test resulted in "generalizing" her instruction, "not translating but doing more or less the same. I think I should've individualized more than I did" (May, interview). For instance, most fieldnotes from classroom observations depict her instruction focusing on test-related strategies or drilling exercises to practice how to identify the correct answers in the English or Spanish versions of the state test. She projected a test sample question on the board, and she worked with the students on a strategy to eliminate the wrong answers in multiple-choice questions. Working as a whole class, she demonstrated the strategy. First, she modeled it using an example from the English version of the test, and then a Spanish example.

\section{Negotiating Contradictions: Noticing as Redefining Practices}

A common pattern across the data shows how Ms. Perez redefined her practices as she negotiated the contextual discourses she encountered during this first year (i.e., district benchmark and state testing, district definition of bilingual students and bilingual classroom, mandate to teach in English). Throughout this process, she affirmed herself as a bilingual teacher who was defining her own ways to approach instruction.

During the school year, Ms. Perez grappled with the existing separation between bilingual students and regular students as a result of district and state policies. The school is organized with "regular" classrooms for those students who have been exited from the classification of English learners and with bilingual classrooms for those students who are still classified as English learners. 
"Complete separation and that's where I was kind of having hard thoughts about it because... it shouldn't be that bilingual is one thing and regular's [an]other" (October, interview). All her students were English learners, classified as bilingual in her district and therefore placed in a bilingual classroom. She acknowledged the contradictory discourse embedded in the mandate to teach in English to all her students except those who were classified as beginning English learners. She identified this as a problem: "They're not even receiving Spanish instruction, but then...they're just not English or Spanish. You know what I mean? They're not good in English, but they're not good in Spanish either. So, now I see how they're getting behind" (October, interview). To negotiate this tension, throughout the year, she tried to find an instructional approach that would suit students' language needs while not compromising the school policy. For instance, in March she decided to intermingle her "Spanish kids" (teacher's label) with the rest of the class, instead of keeping them as a single group. Her instruction in terms of her use of language also changed. She would use Spanish and English with the whole class: not translating but introducing the topic in Spanish and then continuing with the lesson in English or using Spanish to clarify or to further explain a concept. Occasionally, she revoiced a student response in Spanish or she connected the English vocabulary with the corresponding in Spanish (March, fieldnotes). When asked about the rationale for her decision-making, she explained that she wanted all students to value Spanish as a language for learning.

Now they're wanting to learn the Spanish with them [the group receiving instruction in Spanish]. They want to because I focus a bunch like, okay [teacher switches to Spanish] ["like yesterday, I was explaining the hiatus and dipththong. I explained and some didn't understand me because they still don't understand the rules in Spanish, but I explained to all of them, I told them in Spanish: there are many more rules in English; they are more complicated than in Spanish; but in Spanish accents are more difficult. [Original: como ayer (...) estaba explicado los hiatos (...) y diptongos (...) Se los expliqué a todos algunos no me entendían porque no entienden las reglas en español pero lo expliqué a todos y les dije en español: hay muchas más reglas en inglés un poquito más complicadas que en español pero lo que en español es mas difícil son los acentos"] (March, conversation).

Ms. Perez's repertoire of practice showed how she attempted to overcome restrictive contextual discourses such as the lack of materials in Spanish by creating her own or the lack of real time to develop meaningful instruction in Spanish for the group of students by integrating both languages in her instruction with all students. She attempted to redefine her understanding of bilingual education from a more additive perspective (Stritikus \& Garcia, 2003), trying to overcome the restrictive approach of using Spanish only as a way to support English instruction (Palmer, 2011).

Despite the fact that Ms. Perez identified the limitations and negative impact of standardized testing on her students, over time the discourse of testing dominated her instruction and became the ultimate measure for her teaching skills 
and her students' accomplishments. Ms. Perez started her school year analyzing students' responses to a short schoolwide questionnaire about students' goals for the year. She was taken aback by the fact that all her students answered with a variation of "I want to pass the STAAR test." About this, she said: "Their goals are just to pass the STAAR test. ...It broke my heart because I'm [thinking] "wait, wait, wait, no! You gotta read, how are you gonna accomplish that [if not]" (October, conversation). However, throughout the year students' test scores and preparing them to transition to English-only instruction became her main concerns. For instance, most of the lessons I observed focused on drilling exercises for test preparation. By the end of the year, she noticed how most of her practice had focused on drilling students in the strategies they needed to pass the test (i.e., how to eliminate incorrect options from a multiple option question) as opposed to understanding and learning. During our May interview she reflected back on her teaching and what she was able to do with students after testing was over. "I feel that they get it when they're connected to it [topic]; they talk, they learn it, they actually learn it and instead of... what did we do for the STAAR review, ...it was just drilling, it was just really, really drilling, not learning." This illustrates how Ms. Perez built her repertoire of practice by negotiating her understanding of best practice with district and state mandates to prepare students to succeed in the state standardized testing. As a result, "actual learning" seemed to be relegated to any remaining time after the testing window and before the school year is over.

\section{Discussion and Implications}

This case study explored two research questions. First, findings illustrate how a novice bilingual teacher manages to develop a repertoire of practice that responds to students' language and learning needs by questioning practices (research question 1). Second, the study shows how she attempts to redefine her practice negotiating her ideology about teaching bilingual students amidst limiting and contradictory bilingual education discourses (research question 2).

In answering research question 1, the study documented how Ms. Perez's capacity to question practices and to notice students' language and learning needs allowed her to identify and implement different instructional approaches (Barnhart \& van Es, 2015). For instance, she moved from relying on concurrent translation from English to Spanish to an instructional strategy that integrated both languages in a more dynamic way. In addition, her instructional trajectory showed how she initially depended almost exclusively on the school materials and state curriculum to design instruction, and how later during her first year she was able to design activities to build background knowledge to ground students' conceptual understanding. For instance, she used movies in Spanish and English to contextualize the reading of a non-fiction text. Ms. Perez's ability to notice (Amador, 2014) became a key element in her possibility to bridge her understandings about teaching and being a bilingual teacher-her critical 
pedagogical discourse - and the contextual contradictory discourses predominant in her school about bilingual education (Thompson et al., 2013).

Along the way, Ms. Perez repeatedly questioned her practice and the policy constraints to her practice. She challenged contextual discourses that tend to impose ways of doing and thinking about practice while revisiting her own beliefs about what counts as effective practices. In doing so, she appealed to discourse practices that she encountered and internalized through her participation in different communities (Rogoff et al., 1995). For instance, she revisited her own struggles with the Spanish language as she tried to generate teaching materials, and she recalled knowledge learned in her teacher preparation program about the role of background knowledge and language in bilingual students' learning.

In answering research question 2, the study documented how Ms. Perez's repertoires of practice reflect the way she engaged in negotiating prevailing and contested bilingual education discourses. Ms. Perez struggled to counteract the subtractive language ideology predominant in the school discourses (Hinton, 2014; Palmer, 2011). The complexity of a novice teacher trajectory and the impositions of navigating contradictory discourses were evident in the way she engaged in a "discourse of transition" (Palmer, 2011). Her "lowest classroom" (November, conversation) included the group that needed instruction in Spanish. While she was able to identify and highlight students' Spanish language strengths and accomplishments, she still identified them as lagging behind mainly because of their linguistic needs. This shows how her critical pedagogical discourse embraced the tendency shared by many teachers "to equate strong English skills with intelligence while dismissing or ignoring strong Spanish skills; they tend to frame Spanish as a crutch for children that must be left behind to achieve school success" (Palmer, 2011, p. 118).

In conclusion, even though Ms. Perez was able to notice connections between classroom events and bilingual education discourses (Jacob et al., 2010), it is not clear the extent to which her practices enacted her intent to teach bilingually attending to students' language needs. The contextual discourses about language and bilingual education that this bilingual novice teacher needed to negotiate imposed a level of demand on her role that hindered the construction of a repertoire of practices that reflected her beliefs about the use of first language in bilingual instruction. Despite the "ideological clarity" of this novice teacher about what counts as bilingual education (Bartolomé \& Balderrama, 2001), contradictions impregnated her practice and shaped her struggle as she faced students' hope to "pass the test," the school and district pressure of raising students' scores in state standardized testing, and the shrinking spaces (in terms of time and resources, among others) to use the primary language in the classroom (Hinton, 2014; Palmer, 2011).

These findings contribute to the literature on bilingual novice teachers, highlighting the complexities of becoming a bilingual teacher amidst the contradictions of a bilingual and bicultural community that still privileges Englishonly education. The case of Ms. Perez is representative of many novice bilingual teachers in South Texas who enter the profession expecting to contribute to the 
region's bilingual roots. A key implication of this study is that bilingual teacher noticing needs to be further explored as a key component of a bilingual teacher repertoire of practice and as a semiotic tool for teachers to critically bridge personal ideologies and context discourses. For teacher educators, it is a call for action in terms of signaling a persistent disconnect between teacher preparation and the realities of schooling and between theory and practice in bilingual education. Teacher preparation programs "need to keep in mind the realities of teachers' policy contexts and support them not only in negotiating these realities, but also in challenging them, when necessary, to maintain their professional integrity and the cultural and linguistic identities of their students" (Palmer, 2011, p. 119).

\section{Acknowledgments}

I am indebted to the dedicated and passionate fourth grade bilingual teacher who made this research possible by opening the doors of her classroom.

\section{Note}

1. "District Data (2015)" is excluded from the reference list to protect the identity of the study location.

\section{References}

Amador, J. (2014). Professional noticing practices of novice mathematics teacher educators. International Journal of Science and Mathematics Education, 14(1), 217-241. doi:10.1007/s10763-014-9570-9

Anderson, L., \& Olsen, B. (2006). Investigating early career urban teachers' perspectives on and experiences in professional development. Journal of Teacher Education, 57, 359-377.

Arce, J. (2004). Latino bilingual teachers: The struggle to sustain an emancipatory pedagogy in public schools. International Journal of Qualitative Studies in Education, 17(2), 227-246.

Barnhart, T., \& van Es, E. (2015). Studying teacher noticing: Examining the relationship among pre-service science teachers' ability to attend, analyze and respond to student thinking. Teaching and Teacher Education 45, 8393.

Bartolomé, L. I., \& Balderrama, M. V. (2001). The need for educators with political and ideological clarity: Providing our children with "the best." In M. d. I. L. Reyes \& J. J. Halcón (Eds.), The best for our children: Critical perspectives 
on literacy for Latino students (pp. 48-64). New York, NY: Teachers College Press.

Clark, E. R., \& Flores, B. B. (2001). Who am I? The social construction of ethnic identity and self-perceptions in Latino preservice teachers. The Urban Review, 33(2), 69-86.

Clark, E. R., Jackson, L. G., \& Prieto, L. (2011). Identity: A central facet of culturally efficacious bilingual education teachers. In B. B. Flores, R. S. Hernandez \& C. E. Riojas (Eds.), Teacher preparation for bilingual student population (pp. 27-39). New York, NY: Routledge.

Dyson, A. H., \& Genishi, C. (2005). On the case. Approaches to language and literacy research. New York, NY: Teachers College Press.

Franco-Fuenmayor, S. E., Padrón, Y. N., \& Waxman, H. C. (2015). Investigating bilingual/ESL teachers' knowledge and professional development opportunities in a large suburban school district in Texas. Bilingual Research Journal, 38(3), 336-352.

Galindo, R. (2007). Voices of identity in a Chicana teacher's occupational narratives of the self. The Urban Review, 39, 251-280. doi: 10.1007/s11256007-0052-z

García, E. E., \& Jensen, B. T. (2010). Language development and early education of young Hispanic children in the United States. In O. Saracho \& B. Spodek (Eds.), Contemporary perspectives on language and cultural diversity in early childhood education (pp. 27-39). Charlotte, NC: Information Age Publishing.

Gee, J. P. (1990). Social linguistics and literacies: Ideology in discourses, critical perspectives on literacy and education. London, United Kingdom: Taylor \& Francis.

Gibson, S., \& Ross, P. (2016). Teachers' professional noticing. Theory into Practice, 55(3), 180-188. doi: 10.1080/00405841.2016.1173996

Guerrero, M. D. (2003). Acquiring and participating in the use of academic Spanish: Four novice Latina bilingual education teachers' stories. Journal of Latinos and Education, 2, 159-181. doi: 10.1207/S1532771XJLE02 03_03

Gutiérrez, K. D., \& Rogoff, B. (2003). Cultural ways of learning: Individual traits or repertoire of practice. Educational Researcher, 32(5), 19-25.

Hinton, K. A. (2014). "We only teach in English": An examination of bilingual-in-nameonly classrooms. In D. Freeman \& Y. Freeman (Eds.), Research on preparing inservice teachers to work effectively with emergent bilinguals. Advances in research on teaching (pp. 265-289). London, United Kingdom: Emerald Group Publishing Limited.

Isenberg, E., Max, J., Gleason, P., Potamites, L., Santillano, R., Hock, H., \& Hansen, M. (2013). Access to effective teaching for disadvantaged students 
(NCEE 2014- 4001). Washington, DC: National Center for Education Evaluation and Regional Assistance, Institute of Education Sciences, U.S. Department of Education.

Jacobs, V. R., Lamb, L. L. C., \& Philipp, R. A. (2010). Professional noticing of children's mathematical thinking. Journal for Research in Mathematics Education, 41(2), 169-202.

Lopez, J. J. (2006). Dynamic growth in the Rio Grande Valley. Southwest Economy, March/April, 11-13

Lortie, D. C. (1975). Schoolteacher: A sociological study. Chicago, IL: University of Chicago Press.

Musanti, S. I. (2014). "Porque sé los dos idiomas."[Because I know two languages] Biliteracy beliefs and bilingual preservice teacher identity. In Y. Freeman, \& D. Freeman (Eds). Research on preparing preservice teachers to work effectively with emergent bilinguals. Advances in research on teaching (pp. 59-87). Bradford, United Kingdom: Emerald Group Publishing Limited.

Ochoa, G. L. (2007). Learning from Latino teachers. San Francisco, CA: Wiley.

Osterling, J. P., \& Webb, W. (2009). On becoming a bilingual teacher: A transformative process for preservice and novice teachers. Journal of Transformative Education 7(4) 267-293. doi: 10.1177/1541344610386470

Palmer, D. (2011). The discourse of transition: Teachers' language ideologies within transitional bilingual education programs. International Multilingual Research Journal, 5(2), 103-122. doi:10.1080/19313152.2011.594019

Palmer, D., \& Martínez, R. A. (2013). Teacher agency in bilingual spaces: A fresh look at preparing teachers to educate Latina/o bilingual children. Review of Research in Education, 37(1), 269-297.

Prieto, L. (2013). Maestras constructing mestiza consciousness through agency within bilingual education. The Journal of Latino-Latin American Studies, 5(3), 167.

Rogoff, B. (2003). The cultural nature of human development. New York, NY: Oxford University Press.

Rogoff, B., Baker-Sennett, J., Lacasa, P., \& Goldsmith, D. (1995). Development through participation in sociocultural activity. In J. Goodnow, P. Miller, \& F. Kessel (Eds.), Cultural practices as contexts for development (pp. 45-65). San Francisco, CA: Jossey-Bass.

Snyder, C. (2012). Finding the "Royal Road" to learning to teach: Listening to novice teacher voices in order to improve the effectiveness of teacher education. Teacher Education Quarterly, 39(4), 33-53.

Stigler, J. W., \& Hiebert, J. (1999). The teaching gap: Best ideas from the world's teachers for improving education in the classroom. New York, NY: Free Press, Simon \& Schuster. 
Stritikus, T. T., \& Garcia, E. (2003). The role of theory and policy in the educational treatment of language minority students: Competitive structures in California. Education Policy Analysis Archives, 11(26). Retrieved from http://epaa.asu.edu/epaa/v11n26/

Stronge, J. H., Ward, T. J., \& Grant, L. W. (2011). What makes good teachers good? A cross-case analysis of the connection between teacher effectiveness and student achievement. Journal of Teacher Education, 62(4), 339-355. doi: 10.1177/0022487111404241

Sutterby, J. A., Ayala, J., \& Murillo, S. (2005). El sendero torcido al español [The twisted path to Spanish]: The development of bilingual teachers' Spanishlanguage proficiency. Bilingual Research Journal, 29(2), 435-501.

Texas Education Agency (2015). Information on State Assessments for English Language Learners. Retrieved from http://tea.texas.gov/student.assess ment/ell/

Téllez, K. K., \& Varghese, M. M. (2013). Teachers as intellectuals and advocates: Professional development for bilingual education teachers. Theory Into Practice, 52(2), 128-135.

Thompson, J., Windschitl, M., \& Braaten, M. (2013). Developing a theory of ambitious early career teacher practice. American Educational Research Journal, 50(3), 574-615.

Thompson, A. S., \& Fioramonte, A. (2012). Nonnative speaker teachers of Spanish: Insights from novice teachers. Foreign Language Annals, 45(4), 564-579. doi:10.1111/j.1944-9720.2013.01210.x

Uro, G., \& Barrio, A. (2013). English Language Learners in America's great city schools: Demographics, achievement, and staffing. Washington, DC: Council of the Great City Schools.

Varghese, M. M. (2006). Bilingual teachers-in-the-making in Urbantown. Journal of Multilingual and Multicultural Development, 27, 211-224. doi: 10.1080/ 01434630608668776

Yin, R. K. (2003). Case study research. Design and methods ( $3^{\text {rd }}$ ed.). Thousand Oaks, CA: Sage.

Young, R. (2009). Discursive practice in language learning and teaching. West Sussex, United Kingdom: Wiley-Blackwell.

\section{Author Contact}

Sandra I. Musanti: sandra.musanti@utrgv.edu

University of Texas Rio Grande Valley, 1201 W University Dr, BMAIN 2.130 Edinburg, TX 78539 